\title{
Human papillomavirus type 16 DNA in anal cancers from six different countries
}

\author{
J H Scholefield, I B Kerr, N A Shepherd, K J Miller, R Bloomfield, J M A Northover
}

\begin{abstract}
An association between anal squamous cell carcinoma and human papillomavirus (HPV) type 16 DNA has been documented in the UK. If HPV type 16 is an important aetiological factor in the development of this tumour it would be expected to occur in anal cancer tissues from other parts of the world. In this study a series of 173 anal squamous cell carcinoma tissue samples from five centres around the world have been examined by DNA hybridisation for HPV type 16 DNA sequences. HPV type 16 DNA was found in 50 of $173(29 \%)$ of these. The prevalence of HPV associated anal squamous cell carcinoma was significantly lower in tissue from India and South Africa than in the Swiss, Polish, or Brazilian samples. HPV associated anal squamous cell carcinoma does occur in other countries and further investigations of the prevalence of these tumours in association with other HPV types are required.
\end{abstract}

An association between anal squamous cell carcinoma and human papillomavirus (HPV) has recently been shown, HPV type 16 DNA being detected in $56 \%$ of these tumours. ${ }^{1}$ Of the anal squamous cell carcinomas collected in this prospective series over a two year period at $\mathrm{St}$ Mark's Hospital, 23 of 41 (56\%) contained HPV type 16 DNA. These tumours were collected predominantly from southern England. In order to determine whether anal squamous cell carcinomas from other parts of the UK and from other countries contained HPV type 16 DNA, surgeons and pathologists from the UK and from several centres in different countries were asked to submit material for examination.

According to international cancer statistics, anal cancers occur throughout the world, with the highest incidence in Geneva (Switzerland). Other areas of high incidence are Katowice (Poland) and Recife (Brazil). ${ }^{2}$ Genital HPV infection is also known to occur in many different countries throughout the world, though the incidence and prevalence of these infections is poorly documented because of the difficulties of obtaining accurate data on sexually transmissible infections. The area of north eastern Brazil around Recife is of particular interest as the incidence of cervical, vulval, and penile malignancies is particularly high here and these tumours have also been associated with genital HPV infection in similar proportions to anal squamous cell carcinoma. No relation between the incidence rates of genital and anal cancers has been described, although cases of anal cancer have been reported in women who have previously had cervical carcinomas. ${ }^{3}$

\section{Methods}

TISSUE SAMPLES

Anal cancer tissues were requested as unstained tissue sections or as blocks of formalin fixed, paraffin embedded material from pathologists in the UK (via the Pathology Section of the British Society of Gastroenterology) and from pathologists or surgeons in the following countries abroad: Brazil, India, Poland, South Africa, and Switzerland. The histology of all of the specimens received was reviewed by a single consultant histopathologist (NAS) to confirm the diagnosis of invasive anal squamous cell carcinoma.

\section{ALKALINE HYDROLYSIS}

The technique of alkaline hydrolysis was chosen as the most simple method available of screening large numbers of formalin fixed, paraffin embedded tissues. The development of this method and its validation has been described in a separate publication. ${ }^{4}$ Briefly, this method permits extraction of genomic DNA from formalin fixed, paraffin embedded tissue using a single stage tissue hydrolysis in $0.4 \mathrm{M}$ sodium hydroxide to liberate DNA, which is then bound to a nylon membrane and high stringency DNADNA hybridisation $\left(0.2 \times \mathrm{SSC}\right.$ at $\left.68^{\circ} \mathrm{C}\right)$ performed using a ${ }^{32}$ PdCTP labelled HPV type 16 DNA probe. Radiolabelled hybrids are detected by autoradiography. A ${ }^{32} \mathrm{PdCTP}$ labelled Alu DNA probe was used to compare the loading of genomic DNA of samples from different countries.

\section{CONTROLS}

In these experiments formalin fixed, paraffin embedded anal cancer tissue of known HPV type 16 DNA status was used. These tumours had previously been examined for HPV type 16 DNA by both Southern blotting (on fresh tissue) and by alkaline hydrolysis. ${ }^{+}$In addition, purified HPV DNA types 6 and 16 were used as controls for stringency.

\section{POLYMERASE CHAIN REACTION}

Polymerase chain reaction is an in vitro method for the primer directed enzymatic amplification of specific nucleotide sequences. ${ }^{5}$ As a validation of the alkaline hydrolysis technique and also to try and detect low copy number HPV associated anal cancers, a sample of six anal squamous cell carcinoma specimens from each of the five countries outside the UK were examined using the polymerase chain reaction. Polymerase chain reaction was performed by an independent observer (IBK) who had no knowledge of the 
results of the alkaline hydrolysis experiments or of the origins of the specimens.

\section{DNA PREPARATION FOR POLYMERASE CHAIN REACTION}

Single $10 \mu \mathrm{m}$ tissue sections were cut and dewaxed in xylene, as described for the alkaline hydrolysis method above. The tissue was then digested according to the protocol described by Shibata. ${ }^{6}$ Some $5 \mu$ l of the resulting supernatant containing DNA was then used for amplification in the polymerase chain reaction. The method of amplification used in these experiments has been described by Saiki. ${ }^{7}$ The target DNA was amplified using a Cetus thermal cycler (Perkin-Elmer Cetus, Beaconsfield) with the following profile: $94^{\circ} \mathrm{C}$ for one minute, $55^{\circ} \mathrm{C}$ for one minute, and $72^{\circ} \mathrm{C}$ for two minutes for 30 cycles. The primer oligonucleotides sequences used were for HPV type 16 DNA from the E6 region of the genome. ${ }^{8}$

primer 1 5' AAGGCCAACTAAATGTCAC 3' primer 2 5' GCGGATCCCTGCTTTTATACTAACCGG 3' primer $25^{\prime}$ GCGGATCCCTGCTTTTATACTAACCGG
primer $35^{\prime}$ GCGGATCCTGTCTGCTTTTATACTAA 3'

A $10 \mu \mathrm{l}$ portion of each reaction product was electrophoresed on a $1.5 \%$ agarose gel, which was stained with ethidium bromide to identify the HPV DNA bands. Southern blotting was performed using a ${ }^{32} \mathrm{PdCTP}$ labelled HPV type 16 DNA probe to confirm that the bands seen were HPV DNA.

\section{Results}

ALKALINE HYDROLYSIS

Requests for tissues from the UK via the Section of Pathology of the British Society of Gastroenterology yielded 105 specimens from nine centres as far apart as Torquay and Dundee (Table I). Ninety nine of these specimens were confirmed as being invasive anal squamous cell carcinomas. The other six specimens were found

TABLE I Anal squamous cell carcinoma from around $U K$ and human papillomavirus (HPV) type $16 \mathrm{DNA}$ results using alkaline hydrolysis method

\begin{tabular}{lcc}
\hline Centre & Cases & HPV $16+v e(\%)$ \\
\hline Birmingham & 8 & $3 / 8(38)$ \\
Bedford & 12 & $7 / 12(58)$ \\
Dundee & 23 & $11 / 23(48)$ \\
Exeter & 2 & $1 / 2(50)$ \\
Middlesex (London) & 6 & $2 / 6(33)$ \\
Newcastle & 10 & $3 / 10(30)$ \\
Torquay & 19 & $6 / 19(32)$ \\
Chertsey & 16 & $9 / 16(56)$ \\
Bath & 3 & $1 / 3(33)$ \\
Total & 99 & $43 / 99(43)$ \\
\hline
\end{tabular}

TABLE II Percentage of anal squamous cell carcinomas containing human papillomavirus $(H P V)$ type $16 \mathrm{DNA}$

\begin{tabular}{llll}
\hline Country & Cases & $\begin{array}{l}\text { No HPV } \\
16+v e\end{array}$ & $\% H P V+v e$ \\
\hline $\begin{array}{l}\text { United } \\
\text { Kingdom }\end{array}$ & 99 & 43 & 43 \\
$\begin{array}{l}\text { Brazil (São } \\
\text { Paolo) }\end{array}$ & 17 & 8 & 47 \\
$\begin{array}{l}\text { Switzerland } \\
\text { (Geneva) }\end{array}$ & 44 & 19 & 43 \\
$\begin{array}{l}\text { Poland } \\
\text { (Warsaw) }\end{array}$ & 55 & 19 & 35 \\
$\begin{array}{l}\text { South Africa } \\
\text { (Cape Town) }\end{array}$ & 28 & 3 & 11 \\
India (Madras) & 29 & 1 & 3 \\
\hline
\end{tabular}

to be condyloma (1), adenocarcinoma (2), and stromal tissue but no tumour (3): none of these specimens contained any HPV 16 DNA, but the condyloma contained HPV 6/11 DNA. Forty three of $99(43 \%)$ invasive anal squamous cell carcinomas were found to contain HPV type 16 DNA on alkaline hydrolysis. HPV type 6 DNA was detected in one of 105 of the specimens that seemed histologically to be condyloma.

Five of eight foreign centres approached provided specimens. One hundred and fifty three of 167 specimens received $(92 \%)$ were confirmed to be invasive anal squamous cell carcinomas on histological examination. The other 14 lesions were found to be carcinoma in situ (6), adenocarcinoma (5), and necrotic slough inadequate for histological diagnosis (3). Examination of these specimens by the alkaline hydrolysis method for HPV type 16 DNA showed that 50 of 153 contained HPV type 16 DNA. Neither of the anal adenocarcinomas contained any HPV DNA. Two of the six cases of carcinoma in situ also contained HPV type 16 DNA. None of the adenocarcinomas or necrotic slough contained HPV DNA. HPV types 6/11 DNA were not detected in any of the carcinoma specimens. The prevalence of HPV type 16 DNA in the anal cancers is given in Table II. The proportion of HPV type 16 DNA positive anal squamous cell carcinomas from each country is illustrated in the Figure.

Although the amount of DNA liberated from the anal cancer specimens (as measured by the Alu DNA probe) varied from specimen to specimen, comparison of the DNA yields for samples from Brazil (where the greatest proportion of tumours were HPV DNA positive) and India (where the lowest proportion of tumours were HPV DNA positive) were similar. It therefore seems unlikely that the observed differences in the prevalence of HPV type 16 DNA in these tumours were a result of the availability of tumour DNA for hybridisation.

One of $29(3 \%)$ of Indian tumours containing HPV DNA is significantly different from the proportion of anal squamous cell carcinomas containing HPV DNA in the UK, Switzerland, Brazil, and Poland. Using a global $\chi^{2}$ test the Indian and South African anal cancers are statistically significantly different from those of the

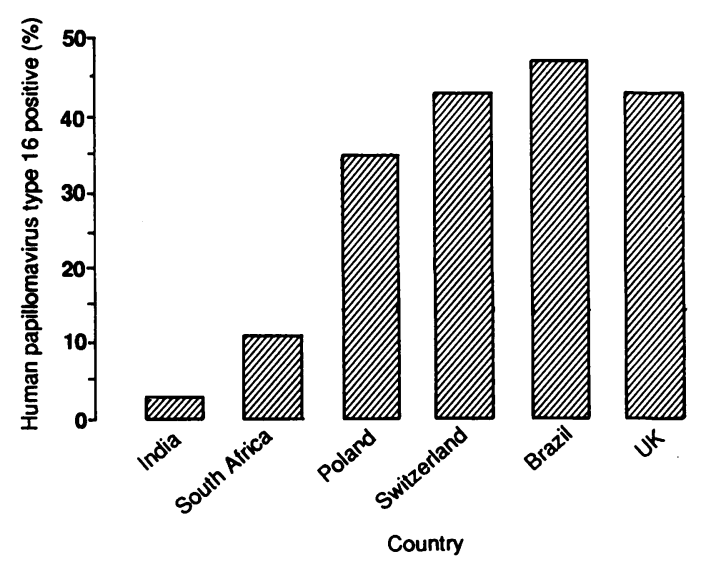

Figure 1: Comparison of the prevalence of human papillomavirus type 16 DNA in anal squamous cell carcinomas from different countries. 
UK, Switzerland, and Poland $\left(\chi^{2}=21 \cdot 3\right.$ $\mathrm{p}<0.001)$.

POLYMERASE CHAIN REACTION

Gel electrophoresis of the polymerase chain reaction product confirmed the results of the alkaline hydrolysis experiment in $\mathbf{2 8}$ of $\mathbf{3 0}$ specimens. Of the two discrepancies that occurred one was in an Indian specimen that was HPV DNA negative by alkaline hydrolysis but was positive by polymerase chain reaction. The other discrepancy occurred in a Brazilian specimen that was positive on alkaline hydrolysis but negative on polymerase chain reaction. The agarose gel showed clear bands in the positive samples at around 200 base pairs but there was also a smear of DNA of smaller fragments which ran just beyond this band. Ths smear made interpretation of the gels more difficult and therefore Southern blotting analysis was performed. This confirmed that the 200 base pair bands seen were HPV type 16 DNA. The smear probably contained oligonucleotides and other DNA fragments that may have been liberated from the fixed tissue.

\section{Discussion}

This is the first study to examine anal cancers from centres outside the UK or United States for HPV type 16 DNA and it has shown that anal cancer tissues from several other countries around the world contain HPV type 16 DNA. There was a noticeable difference in the prevalence of HPV associated anal squamous cell carcinoma in different parts of the world.

The lower prevalence of HPV type 16 associated anal cancer in South Africa is statistically significantly different from the Polish, Swiss, Brazilian, or UK tumours $(p=0.02)$ but accords with the prevalence of HPV type 16 found in South African material from cervical carcinoma in situ (16\%) as reported by Williamson. ${ }^{9}$ These authors comment upon the lower prevalence of HPV type 16 in their own specimens compared with European specimens. Williamson suggests that there may be other HPV types or variants of HPV type 16 that are more prevalent in South Africa.

The differences in the prevalence of HPV type 16 DNA related anal squamous cell carcinoma shown in this study may suggest that other HPV DNA types such as 31 or 33 are implicated in the aetiology of some of these tumours. Similar studies of cervical cancers have shown geographic variations among the different oncogenic HPV types. ${ }^{10}$ In view of the geographic variations in the prevalence of HPV type 16 DNA associated anal cancer, epidemiological studies of the prevalence of genital HPV infections in different countries are required.

It is possible that the HPV DNA detected in some or all of these tumours could be present as a opportunistic infection rather than as an oncogene. In previous studies of anal squamous cell carcinoma in this country using in situ DNA hybridisation, however, none were found to have
HPV DNA on the surface of the tumour, it was located solely in the nuclei of the malignant epithelial cells. ${ }^{1}$ This evidence supports the idea that the HPV DNA is an oncogenic rather than opportunistic agent.

The polymerase chain reaction experiments have provided confirmation of the alkaline hydrolysis results. It is surprising, however, to find that polymerase chain reaction did not detect more HPV containing tumours than the alkaline hydrolysis. This may be explained by a number of factors. Suboptimal amplification of the DNA samples may have occurred; however amplification occurred to some extent otherwise no HPV DNA would have been detected at all. Alternative explanations for not detecting further HPV containing specimens by polymerase chain reaction may be that HPV types other than type 16 exist in some of the tissues but were not amplified because the oligonucleotide primers (designed to bind to the E6/E7 region of HPV 16) did not find complementary sequences with which to anneal. Failure of the primers to anneal would lead to failure of amplification and detection of these alternative HPV types. Synthesis of another set of oligonucleotides from HPV type 18, 31, or 33 and subsequent amplification would be interesting.

In conclusion, this study has shown that HPV associated anal cancer occurs around the world in differing prevalences. This supports the hypothesis that HPV associated anal cancer is not just a local phenomenon occurring in the UK and supports the hypothesis that HPV type 16 infection is an aetiological factor in the development of this tumour. Similar geographic variation has been found in cervical carcinomas. ${ }^{10}$ This study provides data to suggest that oncogenic HPV types may be implicated in anal carcinogenesis in different parts of the world.

The authors are indebted to the following for their assistance in The authors are indebted to the following for their assistance in Talbot, Dr S Price, Mr M Madden, Dr S Widgren, Dr Bielecki, Dr M Nowaki, Prof Rangabashyam, Dr R Dawar, Dr A Banerjee, Dr M Nowaki, Prof Rang
Dr J Baldez, Dr A Booz.

1 Palmer JG, Scholefield JH, Coates PJ, et al. Anal squamous cell carcinoma and human papillomaviruses. Dis Colon Rectum 1989; 32: 1016-22.

2 Muir C, Waterhouse J (eds). In: Cancer in five continents $V$. Lyon, IARC Scientific Publications, 1987.

3 Dixon AR, Pringle H, Watkin D. Anal and cervical intraepithelial neoplasia. Lancet 1989; ii: 1285 .

4 Scholefield JH, McIntyre P, Palmer JG, Coates PJ, Shepherd NA, Northover JMA. Alkaline hydrolysis - a simple, rapid and sensitive technique for the detection of human papillomavirus DNA sequences in formalin-fixed tissue papillomavirus DNA sequences in form
sections. F Clin Pathol 1990; 48: 133-6.

5 Saiki RK, Scharf S, Faloona F, et al. Enzymatic amplification of the B globin genomic sequence and restriction site analysis for diagnosis of sickle cell anaemia. Science 1985; 230: $1350-4$

6 Shibata DK, Arnheim N, Martin WJ. Detection of human papilloma virus in paraffin-embedded tissue using the polymerase chain reaction. $\mathcal{F}$ Exp Med 1988; 167: 225-30

7 Saiki RK, Scharf S, Faloona F, Mullis KB, Horn GT, Erlich HA, Arnheim N. Enzymatic amplification of the B globin genomic sequence and restriction site analysis for diagnosis of sickle cell anaemia. Science 1985; 230: 1350-4.

8 Tidy JA, Vousden KH, Farrell PJ. Relation between infection with a subtype of HPV 16 and cervical neoplasia. Lancet 1989; i: 1225 .

9 Williamson A-L, Dehaeck CMC, Soeters R. Typing of human papillomaviruses in cervical intraepithelial neoplasia grade 3
biopsies from Cape Town. $\mathcal{F}$ Med Virol 1989; 28: 146-9.

10 Pfister H. Biology and biochemistry of papillomaviruses. Rev Physiol Biochem Pharmacol 1984; 99: 111-81. 